\title{
Polyamine Analogue SBP-101
}

National Cancer Institute

\section{Source}

National Cancer Institute. Polyamine Analogue SBP-101. NCI Thesaurus. Code C142788.

An analogue of naturally occurring polyamine (PA), with potential antineoplastic activity. Upon subcutaneous administration, SBP-101 displaces endog enous PAs from PA-binding sites on the cell surface, which prevents internalization of PA. This inhibits PA-dependent cell cycle processes and results in cell cycle arrest, the induction of apoptosis, and inhibition of tumor cell proliferation. PA uptake is upregulated in various tumor types and increased levels of PA leads to enhanced tumor cell growth. 